\title{
Impact of Gender and Location on Mathematical Thinking and Mathematics Achievement
}

\author{
Binod Nepal \\ PhD Scholar, Dr. K.N. Modi University, Newai, Rajasthan, India \\ Email: nepalbinod2071@gmail.com
}

\begin{abstract}
Educational empowerment is taken as the most important indicator of national development. Students' achievement is seen as the key to improve educational empowerment. So to enhance students' achievement we should pay attention to achievements of overall subject of the secondary level, which is the base of further education. This paper aimed to find out the level of Mathematical Thinking and the Mathematics Achievement of the students of grade X in Nepal gender and location wise. Three districts Sindhupalchok, Kathmandu, Mahottari were selected as the study area. 400 students were selected as the sample. Mathematical Thinking Test and Mathematics Achievement Test were used as the instruments and data was analyzed using t-test. Finally, the study found out that there is no significance difference on the level of Mathematical Thinking and the Mathematics Achievement between male and female and there was another finding was that there is significant difference between rural and urban students on the level of Mathematical Thinking and Mathematics Achievement. These findings are applicable to improve teaching strategies and create new plans to make better performance of the students from rural areas.
\end{abstract}

Key words: Gender, Location, Mathematics Achievement, Mathematical Thinking

\section{INTRODUCTION}

There is a huge diversity on the meaning and definition of the term Mathematical Thinking . According to Mason, J.; Burton, L \& Stacy, K. (1991) Mathematical Thinking is a dynamic process which, by enabling us to increase the complexity of ideas we can handle, expands our understanding. Similarly According to Lutfiyya, L. A. (1998), defined Mathematical Thinking 
as a dynamic process that expands our understanding and involves using mathematically rich thinking skills such as guessing, induction, deduction, specification, generalization, analogy, reasoning, and verification. So on, the National Council of Teachers of Mathematics stated that, just as the level of mathematics needed for intelligent citizenship has increased dramatically, so too has the level of Mathematical Thinking and problem solving needed in the workplace and in professional areas ranging from health care to graphic design. Liu, PH; Niess, ML (2006) defined Mathematical Thinking as a combination of complicated processes involving guessing, induction, deduction, specification, generalization, analogy, reasoning, and verification. In this study, Mathematical Thinking is defined as "the development of a mathematical point of viewvaluing the process of mathematization and abstraction and having the predilection to apply them; and the development of competence with tools of the trade and using those tools in the service of the goal of understanding structure" (Schoenfeld, 1992, p. 335).

Mathematical Thinking is the most important part of Mathematics Achievement. According to Stacey Kaye Mathematical Thinking in solving problems is one of the most fundamental goals of teaching Mathematics. Through the improving aspects of Mathematical Thinking students will be able to conduct Mathematical investigations by themselves, and that they will be able to identify where the Mathematics they have learned is applicable in real world situations. (2007). Focusing the necessities of Mathematical Thinking Andrew, P. \& Alistair, stated that it is essential in developing problem solving skills of students in their life (2010). So, Mathematical Thinking is considered one of the most important targets in mathematics education.

Student achievement is seen as the most important indicator of national development. A country cannot develop its socioeconomic situation without enhancing students' achievement. Students' achievement has been focused as one of the keys to alleviating poverty and improving economic competitiveness. In the standards for test construction achievement is viewed basically as the competence a person has in an area of content. This competence is the result of many intellectual and nonintellectual variables. (Greaney \& Kellaghan, 2008b). The Mathematics Achievement is seemed as the marks obtained on mathematics subjects by the students.

Amir Zaman (2011)concluded that male students' mean score was better than that of female students' in all aspect of the Mathematical Thinking and Mathematics Achievements. Male students' mean score in sub-scales of Generalization, Deduction, Problem Solving, Induction and Logical Thinking was higher than female students while for proofs, female 
students scored slightly better than the male students. In his study, most of the teachers perceived that male students were better than female students in the context of Mathematical Thinking. He also found that the Most of the teachers said that urban students were better than their rural counterparts. Urban students mean score was better than that of rural students in all aspect of the Mathematical Thinking and mathematics achievements.

Ma'Moon, Mohammad, Mubark (2005) found there was a significant gender difference for two of the scales and both total scores. Female students had significantly higher scores than male students for Logical thinking, Mathematical proof, and for total Mathematical Thinking and mathematics achievement. There were no gender differences in Mathematical Thinking for the other four aspects. He also identified that Location difference for Mathematics Achievement was also examined. Location was divided in to three parts: rural, sub Urban and Urban. There were significant differences in four of the scales: Generalization, Induction, Use of Symbols, Logical thinking, as well as Mathematical Thinking (total), and Mathematics achievement. For Generalization and Logical thinking, suburban students had higher mean scores than urban students. For Induction, suburban and rural students both had higher mean scores than urban students. For the Use of Symbols, suburban students had higher mean scores than both urban and rural students. For Mathematical Thinking (total) and Mathematics Achievement suburban students had higher mean scores than both rural and urban students. In general, suburban students had the highest scores and urban students the lowest.

Pangeni hold a study on the topic of 'Factors influencing quality of education: A case study of eighth grade students' mathematics learning achievement in Nepal' and concluded that boys were found to perform higher than girls which is statistically and significantly different. His study showed that urban students were found to score higher than rural students. Similarly, students from lowland (Tarai) were found to perform better than those from hill areas. Students from hill areas were found to perform better than those from mountain areas (Pangeni, 2014).

From the study of Nematullah; Yousaf, Muhammad; Gulshan, Allah Bakhsh; Dad, Khaliq it was found that the mathematical approach of urban male students to understand the subjects are better than the urban female and comparatively such type of approach in urban male is better than the rural females. In addition, the performance of rural males is proportionally better than the female of rural areas. But the reflection of results towards the performance of rural males and urban females is not significant. At last it is hypothesized that the overall performance of male 
students in mathematics and its related sciences is better than the female. (Nematullah, Yousaf, Gulshan, \& Dad, 2015). Similarly, Mohd Hasan, Salahuddin Khan had clearly indentified that there was difference between mean scores of Mathematics of male and female students of IX ${ }^{\text {th }}$ grades. The male student had shown significantly higher performance in Mathematics than their female counterpart. (Hasan \& Khan, 2015) Ajai, J.T. \& Imoko, I.I. (2015) found that there is no significant difference between the retention mean scores of male and female students taught algebra using PBL. The report of Education Review Office (NASA 2013) showed the result that the achievement level of the students in the urban schools is remarkably higher than that in rural schools. The difference in average score is significant. It showed a huge disparity between urban and rural students. The difference is remarkably high. There is statistically significant difference in the achievement between boys and girls in Mathematics. It is noteworthy that in all content areas boys have outperformed the girls. However, the effect size is small indicating that the difference is not remarkable. Gender explains only $1 \%$ variation in achievement score. (Poudel, Thapaliya, \& Khanal, 2013).

Generally it is said that our mathematics achievement is low and the failure rate is high. There raised some questions: Is there significant difference on the level of Mathematical Thinking and Mathematics Achievement between Male and Female? Is there significant difference on the level of Mathematical Thinking and Mathematics Achievement between Rural and Urban students'? Research work on this particular field and perspective, investigating the level of Mathematical Thinking and Mathematics Achievement and comparison between different demographical situations in Nepal is necessary to solve those raised questions. So, this study mainly aimed to compare the level of Mathematical Thinking and Mathematics Achievement of grade $\mathrm{X}$ gender and location wise.

\section{METHODS}

This research paradigm is post positivism. This study depends on deductive approaches to compare Mathematical Thinking and Mathematics Achievement. The researcher used mixed methods where both quantitative data i.e. test scores from test of Mathematical Thinking and Mathematics Achievement and qualitative data i.e. interviews from students and teachers were collected simultaneously and both types of data were adopted to address the research hypothesis. The results from both types of instruments were analyzed using both quantitative and qualitative 
methods. The researcher used the Multi Stage Sampling to find the study area. Stratified Random Sampling was also opted. 40 schools were selected from the study area and 400 students 200 male and 200 female were selected as sample from the total population. 150 students were selected from rural and 250 students were selected from the urban areas. Among them 250 students were selected from public and 150 students were selected from private schools. The information was collected directly from the respondents of different areas by using Mathematical Thinking Test MTT (Nepal 2015), Mathematics Achievement Test MAT (Nepal 2015) the tools that was designed as the research instruments. Semi Structured Interview was also used to test the similarities or variance on the result of quantitative result. To indentify the significant difference t-test was used.

\section{RESULT AND DISCUSSION}

Score on the test of Mathematical Thinking and Mathematics Achievement was analyzed in this section for comparison of students in relation to background variables gender, location and school sector, parents education using Independent Sampled t-Test.

\section{Gender-wise Comparison of the Mathematical Thinking and Mathematics Achievement}

200 girls and 200 boys were taken as sample for gender wise comparison. The researcher gave the place for third gender but nobody was found. 75 female students (rural: 5 and urban : 70) participated from private schools in the research and 125 female students (rural : 70 and urban : 55) from public schools. Same number of male students also participated in same criteria i.e. 75 from private (rural: 5 and urban: 70) and 125 from public (rural: 70 and urban: 55).

Table 1: The number of male and Female respondents

\begin{tabular}{|c|c|c|c|c|c|}
\hline \multicolumn{3}{|c|}{ Types of school } & \multicolumn{2}{|l|}{ Gender } & \multirow{3}{*}{\begin{tabular}{|l} 
Total \\
10 \\
\end{tabular}} \\
\hline & & & Female & Male & \\
\hline \multirow{3}{*}{ Private } & \multirow{2}{*}{ Types of location } & Rural & 5 & 5 & \\
\hline & & Urban & 70 & 70 & 140 \\
\hline & \multicolumn{2}{|l|}{ Total } & 75 & 75 & 150 \\
\hline \multirow{3}{*}{ Public } & \multirow{2}{*}{ Types of location } & Rural & 70 & 70 & 140 \\
\hline & & Urban & 55 & 55 & 110 \\
\hline & \multicolumn{2}{|l|}{ Total } & 125 & 125 & 250 \\
\hline Total & Types of location & Rural & 75 & 75 & 150 \\
\hline
\end{tabular}


ISSN: 2362-1303 (Paper) | elSSN: 2362-1311(Online)

JOURNAL OF ADVANCED ACADEMIC RESEARCH (JAAR)

\begin{tabular}{|l|l|l|l|l|l|}
\hline & Urban & 125 & 125 & 250 \\
\cline { 2 - 6 } & Total & 200 & 200 & 400 \\
\hline
\end{tabular}

Source: Field Survey 2015

Our hypothesis was that there is no significant difference between Mathematical Thinking and Mathematics Achievements between male and female students. The score of Mathematical Thinking and Mathematics Achievement are shown in the table below.

Table 2: Gender wise Analysis of Mathematical Thinking and Mathematics Achievement (the mean scores are calculated)

\begin{tabular}{|l|l|l|l|l|}
\hline Scale & Female & Male & t-value & Sig. (2-tailed \\
\hline Deduction & $\begin{array}{l}9.80 \\
(3.680)\end{array}$ & $\begin{array}{l}9.90 \\
(3.652)\end{array}$ & -.286 & .775 \\
\hline Induction & $\begin{array}{l}5.06 \\
(3.475)\end{array}$ & $\begin{array}{l}5.17 \\
(3.427)\end{array}$ & -.304 & .761 \\
\hline Logical Thinking & $\begin{array}{l}5.80 \\
(3.731)\end{array}$ & $\begin{array}{l}6.30 \\
(4.541)\end{array}$ & -1.203 & .230 \\
\hline Generalization & $\begin{array}{l}5.18 \\
(3.727)\end{array}$ & $\begin{array}{l}5.39 \\
(3.591)\end{array}$ & -.574 & .566 \\
\hline Mathematical Proof & $\begin{array}{l}5.74 \\
(5.038)\end{array}$ & $\begin{array}{l}5.93 \\
(4.692)\end{array}$ & -.401 & .689 \\
\hline Problem solving & $\begin{array}{l}6.18 \\
(5.000)\end{array}$ & $\begin{array}{l}5.94 \\
(4.808)\end{array}$ & -.480 & .632 \\
\hline Mathematical Thinking Total & $\begin{array}{l}37.47 \\
(19.467)\end{array}$ & $\begin{array}{l}38.33 \\
(18.187)\end{array}$ & -.454 & .650 \\
\hline Mathematical achievement Total & $\begin{array}{l}40.91 \\
(23.126)\end{array}$ & $\begin{array}{l}42.58 \\
(22.204)\end{array}$ & -.734 & .463 \\
\hline \multicolumn{2}{|l|}{ Standard deviation is in paraphrasing } \\
\hline
\end{tabular}

Source: Field Survey 2015

From above table it is noticed that Female students obtained the highest mean scores 9.80 in the Deduction and the least score 5.06 was obtained in Induction. Similarly, Male students obtained highest mean score 9.90 in Deduction and least score 5.17 was obtained in Induction. Female students had 5.80, 5.18, 5.74, 6.18 mean score in Logical Thinking, Generalization, Mathematical Proof and Problem Solving respectively. Likewise, male students had 6.30, 5.39, 5.93, 5.94 mean scores in Logical Thinking, Generalization, Mathematical Proof and Problem Solving respectively. Female students had the total mean scores in Mathematical 37.47 but male students obtained 38.33 mean score. The total mean score in Mathematics Achievement of Female was 40.91 and that of male students was 42.58. Male students' mean score was little better than that of female students in five aspect of the Mathematical Thinking (Deduction, 
Induction, Logical Thinking, Generalization, Mathematical Proof), Mathematical Thinking (Total) and Mathematics Achievement (Total). But the mean score of female students in one aspect of Mathematical Thinking i.e., Problem Solving was better than that of male students. Table 2 also shows there is no significant difference between every aspects of Mathematical Thinking and Mathematics Achievement among male and female students of grade $\mathrm{X}$. There is no significant difference between Mathematical Thinking (Total) and Mathematics Achievement (Total) among the Male and Female students in every aspects of Mathematical Thinking. There is no difference between the male and female on the level of Mathematical Thinking and the Mathematics Achievement on the female and male teachers' perspective who were interviewed.

\section{Location-wise Comparison of the Mathematical Thinking and Mathematics Achievement}

150 students were taken from rural and 250 students from urban area of three different districts Sindhupalchok, Kathmandu and Mahottari. Among them 75 male and 75 Female students were participated in the research from rural area of those districts. 125 female and 125 male students were selected for research. In total 150 (75 male and 75 Female) were taken as sample from private school and 250 (125 male and 125 female) students from Public schools. The number of students from Rural and Urban area is shown in the table below.

Table 3: The number of students from Rural and Urban area

\begin{tabular}{|c|c|c|c|c|c|}
\hline \multirow{2}{*}{\multicolumn{3}{|c|}{ Types of school }} & \multicolumn{2}{|c|}{ Types of location } & \multirow[t]{2}{*}{ Total } \\
\hline & & & Rural & Urban & \\
\hline \multirow{3}{*}{ Private } & \multirow{2}{*}{ Gender } & Female & 5 & 70 & 75 \\
\hline & & Male & 5 & 70 & 75 \\
\hline & \multicolumn{2}{|l|}{ Total } & 10 & 140 & 150 \\
\hline \multirow{3}{*}{ Public } & \multirow{2}{*}{ Gender } & Female & 70 & 55 & 125 \\
\hline & & Male & 70 & 55 & 125 \\
\hline & \multicolumn{2}{|l|}{ Total } & 140 & 110 & 250 \\
\hline \multirow{3}{*}{ Total } & \multirow{2}{*}{ Gender } & Female & 75 & 125 & 200 \\
\hline & & Male & 75 & 125 & 200 \\
\hline & \multicolumn{2}{|l|}{ Total } & 150 & 250 & 400 \\
\hline
\end{tabular}

Source: Field Survey 2015

The researcher emphasized to find "Is there significant difference between Mathematical Thinking and Mathematics Achievement among the Rural Areas' students and Urban Areas' 
Students?" So the level of Mathematical Thinking and Mathematics Achievement are shown in the table below. There is shown the mean score of students' from Rural and Urban area. The comparison is tested using Independent Sample t-Test.

Table 4: Gender wise Analysis of Mathematical Thinking and Mathematics Achievement (the mean scores are calculated)

\begin{tabular}{|l|l|l|l|l|}
\hline Scale & Rural & Urban & t-value & p-value \\
\hline Deduction & $\begin{array}{l}8.57 \\
(3.672)\end{array}$ & $\begin{array}{l}10.61 \\
(3.443)\end{array}$ & -5.50 & .000 \\
\hline Induction & $\begin{array}{l}4.46 \\
(3.517)\end{array}$ & $\begin{array}{l}5.50 \\
(3.351)\end{array}$ & -2.96 & .004 \\
\hline Logical Thinking & $\begin{array}{l}4.88 \\
(3.356)\end{array}$ & $\begin{array}{l}6.75 \\
(4.433)\end{array}$ & -2.92 & .000 \\
\hline Generalization & $\begin{array}{l}4.29 \\
(3.086)\end{array}$ & $\begin{array}{l}5.88 \\
(3.844)\end{array}$ & -4.46 & .000 \\
\hline Mathematical Proof & $\begin{array}{l}4.95 \\
(4.322)\end{array}$ & $\begin{array}{l}6.36 \\
(5.095)\end{array}$ & -4.77 & .005 \\
\hline Problem solving & $\begin{array}{l}5.40 \\
(4.831)\end{array}$ & $\begin{array}{l}6.40 \\
(4.911)\end{array}$ & -4.29 & .060 \\
\hline Mathematical Thinking Total & $\begin{array}{l}31.87 \\
(17.510)\end{array}$ & $\begin{array}{l}41.51 \\
(18.683)\end{array}$ & -5.11 & .000 \\
\hline Mathematical achievement Total & $\begin{array}{l}35.37 \\
(19.123)\end{array}$ & $\begin{array}{l}45.56 \\
(23.761)\end{array}$ & -4.45 & .000 \\
\hline Standard deviation is in paraphrasing & \multicolumn{5}{|l}{} \\
\hline
\end{tabular}

Source: Field Survey 2015

According to the table 4, the students from rural area secured 8.57, 4.46, 4.88, 4.29, 4.95, 5.40 marks in Deduction, Induction, Logical Thinking, Generalization, Mathematical Proof and Problem Solving. The rural school students felt easy on the Deduction aspect of the Mathematical Thinking securing the highest mean score 8.57. They secured the least mean score 4.46 on the Induction aspect of Mathematical Thinking. On the above table, The students from Urban area obtained 10.61, 5.50, 6.75, 6.36, 5.88, 6.40 score in Deduction, Induction, Logical Thinking, Generalization, Mathematical Proof and Problem Solving. The students from Urban area secured the highest mean score 10.61 in Deduction and the least mean score 5.50 in Generalization. The Important fact was found that, in every aspects of Mathematical Thinking. The students from Urban area were more forward than those of rural area. Students from Rural area secured 31.87 mean score in Mathematical Thinking and 35.37 in Mathematics Achievement. The students from Urban area secured 41.51 mean score in Mathematical 
Thinking and 45.56 in Mathematics Achievement. It showed that the students from Urban area were more forward rather than those of rural area.

To find the significance difference in the mean score, Independent Sample t-Test was used comparing urban and rural students' mean scores in the test of Mathematical Thinking, Mathematics Achievement and all six aspects of Mathematical Thinking. The results shown in the above table stipulated that the mean score of the students from Urban area was better than those of rural area in all aspect of the Mathematical Thinking and mathematics achievements. There is significant difference in the four aspects of Mathematical Thinking i.e., Deduction, Induction, Logical Thinking, Generalization, and Mathematical Proof. However there is no significant difference in the problem solving between the Rural and Urban areas' students. Finally, there was no significant difference between the level of Mathematical Thinking and Mathematics Achievement of grade X students between the Rural and Urban area. The level of Mathematical Thinking and the Mathematics Achievement on urban area was better than rural areas students' on the views of both urban and rural areas' teacher who were participated on the study.

\section{CONCLUSION}

The study can be concluded that there was no significant difference between every aspects of Mathematical Thinking and Mathematics Achievement between male and female students of grade X. There was no significant difference between Mathematical Thinking (Total) and Mathematics Achievement (Total) among the male and female students in every aspects of Mathematical Thinking. There was significant difference in the four aspects of Mathematical Thinking i.e., Deduction, Induction, Logical Thinking, Generalization, and Mathematical Proof. But there was no significant difference in the Problem Solving among the students from Rural and Urban area. Finally, there was significant difference between the level of Mathematical Thinking and Mathematics Achievement among grade X students from Rural and Urban area.

From above findings of the study, it is suggested that it is necessary for students to enhance their Mathematical Thinking and Mathematics Achievements in the rural area. Teachers' teaching strategies, availability of teaching materials and other references, teachers' qualification and experience may be the factors that could be found in the further researches. To improve the students' mathematics achievement in the rural areas Ministry of Education should prepare and 
imply the effective plan. Teachers of rural areas should pay attention to improve students' Mathematical Thinking and mathematics Achievement. Teacher Trainers should be concerned to hold training package and conduct Mathematics teachers' training to develop the students' Mathematical Thinking and Mathematics Achievement in rural area. It is also recommended for further research in order to fill up the possible research gaps on this study.

\section{REFERENCES}

Ajai, J., \& Imoko, I. (2015). Gender differences in Mathematics Achievement and retention scores: A case of problem-based learning method. International Journal of Research in Education and Science (IJRES) , 1 (1), 45- 50.

Andrew, P., \& Alistair. (2010). Andrew, P., \& Alistair, C. (2010). Information Technology in University Level Mathematics Teaching and Learning: A Mathematician's point of view.

Greaney, V., \& Kellaghan, T. (2008b). National assessments of educational achievement: Assessing national achievement levels in education (Vol. 1). the World Bank.

Hasan, M., \& Khan, S. (2015). Academic Achievement Test in English and Mathematics of Secondary School Students in relation to Gender Differences. The International Journal of Indian Psychology , 2 (3), 155-166.

Liu, P., \& Niess, M. (2006). An exploratory study of college students' views of Mathematical Thinking in a historical approach calculus course, Math. Think. Learn, 8 (4), 373-406.

Lutfiyya, L. A. (1998). Mathematical Thinking of High School Students in Nebraska. International Journal of Mathematics Education and Science Technology. , 29 (1), 55-64.

Ma'Moon, M. (2005). Mathematical Thinking and Mathematics Achievement of Students in the year 11 in the scientific Stream in Jorden. Faculty of Education and Arts. Austrilia: The University of Newcastle.

Mason, J., Burton, L., \& Stacy, k. (1991). Thinking mathematically. England: Addison-

Wesley, Wokingham.

Nematullah, Yousaf, M., Gulshan, A. B., \& Dad, K. (2015). An Analytical Study of Gender Difference in Academic Achievement in Mathematics at Secondary Level. British Journal of Education, Society \& Behavioural Science, 11 (4), 1-7.

Pangeni, K. P. (2014). Factors influencing quality of education: A case study of eighth grade students' mathematics learning achievement in Nepal. Japan: Graduate School of International Development Nagoya University (unpublished Phd Dissertation). 
Poudel, D. L., Thapaliya, D. T., \& Khanal, D. P. (2013). Report on National Assessment of Student Achievement. sanothimi, Bhaktapur ,Nepal: Government of Nepal,Ministry of Education,Education Review Office.

Schoenfeld, A. H. (1992). Learning to think Mathematically: Problem Solving. Metacognition, and Sense Making in Mathematics.

Stacey, K. (2007). what is Mathematical Thinking , Why is it Important? Australia: University of Melbourne.

Zaman, A. (2011). Relation between Mathematical Thinking and Achievement in Mathematics among Secondary School Students of North West Frontier Province, Pakistan. Faculty of social sciences, Department of Education. Islamabad: International Islamic University. 